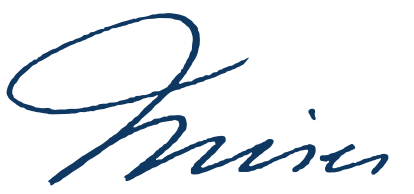

\title{
Direito, Justiça e Democracia em uma Ordem Liberal Segundo F. A. Hayek
}

\author{
Anderson Paz ${ }^{I}$ (1) 0000-0001-7799-3707 \\ Universidade Federal da Paraíba, João Pessoa, Paraíba, Brasil
}

Resumo: No presente trabalho, visa-se a discutir a concepção de direito, justiça e democracia em uma ordem liberal para F. A. Hayek. Utiliza-se de metodologia exploratória, através de revisão bibliográfica, que se concentra, principalmente, na obra hayekiana Direito, Legislação e Liberdade. Destacar-se-ão as noções de normas de conduta justa, de descobrimento das leis e o papel do juiz, de justiça associal e de demarquia como um retorno ao ideal democrático. O objetivo de Hayek era evitar que as sociedades ocidentais adentrassem o caminho da servidão. Porém, a relação entre direito, democracia e justiça em Hayek levantam questões e críticas importantes, a saber, a liberdade e a justiça são concebidas apenas em seu sentido negativo, a democracia é entendida apenas nos sentidos formal e procedimental, e ao juiz é atribuído o dever de assumir um papel de Hércules no descobrimento da norma mais adequada aos casos concretos.

Palavras-chave: F. A. Hayek, Direito, Democracia, Justiça, Ordem Liberal.

\footnotetext{
I Mestre em Ciência Política e Relações Internacionais pela Universidade Federal da Paraíba. Bacharel em Direito pela Universidade Federal da Paraíba. Bacharel em LEA Negociações Internacionais pela Universidade Federal da Paraíba. Graduando de Licenciatura em Filosofia pela Universidade Cruzeiro do Sul. E-mail: andersonbarbosapaz@gmail.com.
} 


\title{
Law, Justice and Democracy in a Liberal Order According to F. A. Hayek
}

\begin{abstract}
This paper aims to discuss the concept of law, justice and democracy in a liberal order for F. A. Hayek. Exploratory methodology is used through a bibliographic review that focuses mainly on the hayekian work Law, Legislation and Liberty. The notions of rules of just conduct, of discovering the laws and the role of the judge, non-social justice and demarquia as a return to the democratic ideal will be highlighted. The Hayeks's aim was to prevent Western societies from entering the road to serfdom. However, the relationship between the law, democracy and justice in Hayek raises important questions and criticisms, namely, freedom and justice are conceived only in their negative sense, democracy is understood only in the formal and procedural sense, and the judge assumes the role of Hercules in the discovery of the most appropriate norm for specific cases.
\end{abstract}

Keywords: F. A. Hayek, Law, Democracy, Justice, Liberal Order.

\section{Derecho, Justicia y Democracia en un Orden Liberal Según F. A. Hayek}

Resumen: Este artículo tiene como objetivo discutir el concepto de derecho, justicia y democracia en un orden liberal para F. A. Hayek. Se utiliza metodología exploratoria a través de una revisión bibliográfica que se centra principalmente en la obra hayekiana Derecho, Legislación y Libertad. Se resaltarán las nociones de leyes de conducta justa, de descubrimiento de las leyes y el rol del juez, justicia no social y demarquia como retorno al ideal democrático. El objetivo de Hayek era evitar que las sociedades occidentales entraran en el camino de la servidumbre. Sin embargo, la relación entre derecho, democracia y justicia en Hayek plantea importantes interrogantes y críticas, a saber, la libertad y la justicia se conciben solo en su sentido negativo, la democracia se entiende solo en el sentido formal y procesal, y al juez se atribuye el deber de asumir el papel de Hércules en el descubrimiento de la norma más adecuada para casos concretos.

Palabras clave: F. A. Hayek, Derecho, Democracia, Justicia, Orden Liberal. 


\section{Introdução}

No começo do século XX, havia muita discussão nos países europeus sobre como governos democráticos deveriam expandir seu papel no sentido de efetivar a justiça social. O jovem austríaco Friedrich August von Hayek (1899-1992) passou a alertar que as ideias coletivistas da sociedade e da economia causariam conflitos econômicos e políticos.

A preocupação hayekiana se dava em que a máquina administrativa se expandisse e absorvesse a esfera privada. Para Hayek, a fórmula do Estado de Direito no Ocidente estava sendo corrompida pelo ideal de justiça social democrática que prometia expandir direitos sociais diminuindo a liberdade dos indivíduos. O Estado Social entregaria crises e levaria ao caminho da servidão.

Em texto anterior (PAZ, 2020), foram discutidos os fundamentos do Estado de Direito no pensamento hayekiano. Para o autor austríaco, a liberdade deve ser negativa, isto é, o indivíduo não deve ser coagido a fazer a vontade de outrem, salvo se a coerção se der de modo abstrato e imparcial com base em princípios gerais esposados nas leis impostas a todos. O império da lei deve garantir a imparcialidade estatal por meio de normas de conduta justa que limitam o governo. E as normas não devem ser criadas de forma racionalista, mas sim como resultado de uma ordem espontânea da qual se descobrem as leis que funcionam para uma Sociedade Aberta.

Com efeito, as doutrinas do Estado de Direito e democracia não podem ser dissociadas. Ademais, após a Teoria da Justiça (1971) de John Rawls, a discussão sobre aquilo que é justo para uma sociedade entrou definitivamente em pauta nos estudos de filosofia política. Logo, direito, justiça e democracia, hodiernamente, não podem ser discutidos separadamente.

Dessa maneira, é fundamental compreender como Hayek relacionou direito, justiça e democracia em um Estado de Direito. No presente trabalho, visa-se a discutir a concepção de direito, justiça e democracia em uma ordem liberal para F. A. Hayek. Para tanto, serão destacados os seguintes temas desenvolvidos no pensamento hayekiano: direito e liberdade, descobrimento das leis e o papel do juiz, justiça associal e demarquia como um retorno ao ideal democrático.

Para isso, adotar-se-á uma metodologia exploratória através de revisão bibliográfica. A abordagem será qualitativa por se tratar de um trabalho teórico. E o estudo se concentrará, primordialmente, nos três volumes da obra hayekiana Direito, Legislação e Liberdade. Essa obra foi publicada originalmente na década de 1970 e evidencia as preocupações de Hayek sobre o progressivo desvirtuamento do direito, da justiça e da democracia em sociedades livres.

Segundo Hayek, em uma ordem livre, o direito é caracterizado por normas de conduta justa que promovem a liberdade, o juiz é descobridor de normas a partir de uma tradição jurisprudencial que aperfeiçoa o império do direito, a justiça é imparcial e formal não assumindo características específicas, e a democracia é um método formal de troca de poder.

A proposta hayekiana de Estado de Direito consiste na volta ao modelo liberal clássico que se interpõe ao coletivismo em sociedades livres. Porém, a relação entre direito, democracia e justiça em Hayek levanta questões e críticas importantes, a saber, a liberdade e a justiça são concebidas apenas em seu sentido negativo, a democracia é entendida apenas nos sentidos 
formal e procedimental, e ao juiz é atribuído o dever de assumir um papel de Hércules no descobrimento da norma mais adequada aos casos concretos.

\section{Direito e Liberdade}

De acordo com Hayek (1985a), sociedades livres são orientadas por normas que, através de um processo histórico de seleção, evoluíram ao longo do tempo como resultado da experiência de gerações passadas. Nesse sentido, as normas que orientam uma sociedade livre são resultado da ação humana consolidada ao longo do tempo e não de um construtivismo racionalista governamental.

A partir desse pressuposto, Hayek (1985a) formula sua concepção de ordem espontânea (kósmos), a saber, uma ordem não criada racionalmente, mas sim resultado de um processo de erros e acertos históricos sem propósitos específicos que só pode ser reconstruída de forma abstrata na mente humana. Dessa ordem derivam os princípios gerais que orientam uma sociedade livre. Tais princípios são resultado de uma evolução social não intencional que acumulou conhecimento e consolidou condutas já aprovadas. Essa ordem possibilita um direito emanado dos costumes e precedentes consolidados ao longo do tempo.

Dessa forma, Hayek (1985a) sustenta que o direito não pode ser criado racionalmente e deve ser caracterizado pelo império da lei (nomos) através de "normas abstratas de conduta" passíveis de serem descobertas como resultado da ordem espontânea. Essas normas são aquelas que independem de fins e servem à formação de uma ordem espontânea.

Para Hayek, em regra, as normas jurídicas podem ser descobertas como fruto de uma ordem espontânea, salvo algumas normas que são criadas intencionalmente pelo governo para manter e aperfeiçoar a ordem espontânea. Tais normas de uma sociedade livre devem ser abstratas, imparciais, prévias e não podem submeter discricionariamente a vontade do indivíduo à volição de terceiro. Nesse sentido, Hayek (1985a, p. 99) afirma que:

O direito consistirá em normas independentes de propósito que regem a conduta dos indivíduos uns em relação aos outros, destinam-se a ser aplicadas a um número desconhecido de situações futuras e, ao definir o domínio protegido de cada um, possibilitam a formação de uma ordem de ações em cuja esfera os indivíduos podem fazer planos exequíveis.

A partir disso, Hayek (1985a, p. 127) argumenta que o propósito das normas jurídicas é impedir "que as ações de diferentes indivíduos interfiram umas nas outras; elas por si mesmas não podem determinar o resultado que diferentes indivíduos obterão". As normas legais só podem ser imparciais se universalizáveis a todos indiscriminadamente, retirandolhes a discricionariedade que diminui a liberdade dos indivíduos a partir da arbitrariedade do governo. Nesse sentido, Hayek (1985b, p. 170) sustenta que

Só estendendo as normas de conduta justa às relações com todos os outros homens e, ao mesmo tempo, privando de seu caráter compulsório as normas que não podem ser universalmente aplicadas é que conseguiremos aproximarmos de uma ordem universal de paz tendente a integrar todos os seres humanos numa única sociedade. 
Dessa forma, em uma sociedade livre, os indivíduos só podem ser obrigados a obedecer às normas abstratas que delimitam para todos os meios, mas não os fins. Assim, as normas de conduta justa só são normas gerais se se aplicarem a todos e não dispuserem de fins específicos que justifiquem a coerção arbitrária. Por isso, Hayek considera que a liberdade é a ausência de coerção discricionária, isto é, a coerção não amparada em normas gerais. $\mathrm{O}$ autor define coerção como

O controle exercido sobre uma pessoa por outra em termos de ambiente ou de circunstâncias, a ponto de, para evitar maiores danos, aquela ser forçada a agir para servir aos objetivos desta e não de acordo com um plano coerente que ela própria elaborou (HAYEK, 1983, p. 17).

Dessa maneira, ao passo que a coerção anula a vontade dos indivíduos, a liberdade é a capacidade de autodeterminação sobre a qual ninguém pode interferir. Ou seja, a liberdade é ausência de coerção arbitrária sobre o indivíduo. A esfera privada do indivíduo deve ser protegida da intervenção externa que submete o agente à servidão.

Ainda assim, Hayek (1983) reconhece que a liberdade absoluta é impossível, posto que para haver liberdade em uma sociedade livre é preciso que certo grau de coerção seja legitimado através de normas gerais estabelecidas pelo Estado. As normas de conduta justa, então, devem ser abstratas, imparciais e prévias, a fim de que os indivíduos, dentro dos limites das normas gerais, exerçam sua liberdade. A coerção presente nessas normas passa a ser um instrumento do indivíduo na busca de seus próprios objetivos, posto que estabelece limites para todos, inclusive para o governo, e possibilita aos atos dos indivíduos previsibilidade e segurança jurídicas.

A liberdade, assim, é a ausência de coerção arbitrária sobre a esfera privada do indivíduo. Exercer a liberdade "não depende da aprovação de pessoa ou autoridade e tem como único limite as mesmas normas abstratas aplicáveis igualmente a todos" (HAYEK, 1983, p. 171). Direito e liberdade, dessa maneira, estão em estreita relação, posto que as normas são delineadas no sentido de uma coercibilidade geral e imparcial que a todos limitam.

Nesse sentido, a lei é caracterizada como uma norma geral "prescrita para pessoas desconhecidas, independentemente de qualquer circunstância específica de tempo e lugar" (HAYEK, 1983, p. 165). A norma deve ser, então, caracterizada pela abstração ou generalidade, pelo caráter negativo de limitação da ingerência do governo sobre a liberdade individual, e deve ser instrumental para que o indivíduo a utilize no cálculo do exercício racional de sua liberdade.

Sobre esse fundamento é que se sustenta o Estado de Direito e o império da lei. Quando as leis governam, a legitimidade é assegurada e a arbitrariedade limitada. Pois, "quando obedecemos às leis, no sentido de normas gerais abstratas estabelecidas, independentemente de sua aplicação concreta, não estamos submetidos à vontade de outrem e, portanto, somos livres" (HAYEK, 1983, p. 169).

Segundo Hayek, o Estado de Direito é um ideal político que deve limitar o legislador e o governo que, por sua vez, só é legitimado a invadir a esfera privada do indivíduo se este violar alguma norma geral previamente conhecida. Por isso, as normas devem ser, além de 
gerais e imparciais, conhecidas, claras e constantes. Assim, "o ideal da supremacia da lei exige que o Estado faça valer a lei sobre os cidadãos - e que isto seja seu único monopólio - ou deva obedecer à mesma lei, sofrendo assim as mesmas limitações que qualquer cidadão" (HAYEK, 1983, p. 256).

\section{Common Law: O Papel do Juiz}

Segundo Hayek (1985b), a principal tradição jurídica racionalista é o positivismo jurídico. Em sua forma embrionária, John Austin entendia que todo direito é estabelecido por uma mente pensante, de modo que não podia haver lei sem um ato legislativo. Em uma versão mais recente, Hans Kelsen, em A Teoria Pura do Direito (1934), defende que as normas prescritivas só podem emanar da vontade, de forma que o conteúdo de todas as normas jurídicas seja deliberadamente criado por um ato de vontade. Cabe sobre a norma um juízo tão-somente de validade, isto é, de adequação às normas procedimentais.

Logo, na versão positivista kelseniana, a vontade do legislador determina o conteúdo da lei. O justo é determinado pelo conteúdo da lei formal e válida. Na busca de encontrar critérios objetivos de justiça, o positivismo jurídico propôs que todas as questões de justiça eram uma questão de vontade. Dessa forma, os critérios objetivos de justiça devem ser critérios positivos, ou seja, premissas das quais todas as normas de conduta justa poderiam ser deduzidas logicamente.

Para Hayek (1985b), o positivismo jurídico faz com que o juiz fique limitado pela designação legislativa de algumas normas específicas válidas e pelas exigências de um sistema que não foi criado como um todo coerente, dificultando sua aplicação aos casos concretos. Essa formulação positivista é antiliberal por possibilitar a onipotência do legislativo ao pressupor que é possível determinar a ordem social.

Com efeito, Hayek (1985b) entende que a tradição do common law preserva a liberdade ao reconhecer a tradição e o espírito da lei que sustentam a sociedade. É fruto da formação de normas de justiça por evolução espontânea através do tempo. O direito e as liberdades que do common law derivam não são produtos de uma mente consciente, mas sim o resultado de processos de seleção e evolução que a razão do indivíduo pouco controla.

Por sua vez, o juiz descobre o direito para um caso concreto a partir de princípios gerais respeitando a ordem social. Ou seja, em uma sociedade livre, o magistrado é uma instituição de uma ordem espontânea que "é chamado a corrigir perturbações de uma ordem que não construída por ninguém e que não se funda no fato de os indivíduos terem recebido determinações sobre o que fazer" (HAYEK, 1985a, p. 110). Seu trabalho é intelectual, pois descobre, seleciona e aplica normas que aperfeiçoam a ordem espontânea.

Como explica Pievatolo (2006), Hayek sustenta que o common law torna o direito previsível ao vincular o juiz às difusas convicções sobre aquilo que é justo. A treinada intuição do juiz o conduz a resultados acertados ao reconhecer o direito como uma norma cujo caráter vinculante está difusamente reconhecido, podendo estar expresso em lei positiva ou na tradição oral. 
De acordo com o autor austríaco (1985b), o magistrado deve manter as relações abstratas, enquanto que os elementos específicos mudam. Deve conservar a ordem com base em normas de conduta gerais, não aplicando-as conforme os fins particulares de cada um. Os juízes devem tão-somente aperfeiçoar as normas, podendo preencher a lacuna no corpo de normas já reconhecido a fim de manter e aprimorar a ordem de ações possibilitadas pelas normas existentes. Em suma, o magistrado só descobre as normas não enunciadas até então e as aplica aos casos concretos.

Nesse sentido, Hayek (1985a) postula que o objetivo do magistrado é aperfeiçoar a ordem espontânea ao estabelecer uma norma que impeça a recorrência de conflitos análogos. Ele deve considerar as normas observadas na prática social e as que foram criadas pelo governo, considerando a conduta regular dos indivíduos, a fim de aplicar da melhor forma a jurisprudência. Dessa maneira, o papel do juiz é "descobrir as implicações contidas no espírito de todo o sistema de normas legais válidas ou expressar como uma norma geral, quando necessário, o que não foi enunciado previamente por um tribunal de justiça ou pelo legislador" (HAYEK, 1983, p. 258).

Assim, segundo Hayek (1985a), o juiz deve se esforçar no processo de adaptação da sociedade a aplicar as normas abstratas às circunstâncias surgidas no desenvolvimento da ordem espontânea. Ele ajuda no processo de seleção confirmando as normas que tornam mais provável a correspondência das expectativas entre os indivíduos. O magistrado torna-se um órgão dessa ordem que serve na manutenção e aperfeiçoamento do funcionamento da ordem existente. Ainda assim, suas decisões só devem ser mantidas se forem passíveis de serem testadas racionalmente contra as objeções que possam ser levantadas contra ela.

Em casos complexos, Hayek (1983) sustenta que o juiz deve decidir como as normas gerais podem ser aplicadas considerando o sistema legal como um todo. Como nem todas as normas estão explicitadas no ordenamento, o magistrado deve reconhecer normas implícitas ao sistema ao conduzir a decisões coerentes e previsíveis. Deve, portanto, descobrir as consequências contidas no espírito do sistema de normas gerais, expressando o que não foi previamente declarado por um tribunal ou pelo legislador.

Em resumo, o magistrado é uma instituição da ordem espontânea que deve descobrir ou aperfeiçoar - não criar - as normas. Deve aperfeiçoá-las ao torná-las mais precisas e descobri-las quando nunca foram enunciadas. Os juízes devem preencher as lacunas do corpo de normas já reconhecido, mantendo e aprimorando a ordem de ações prevista pela lei. Eles devem aperfeiçoar uma ordem de ações dada, estabelecendo uma norma que obste a recorrência dos conflitos ocorridos.

Nesse sentido, o juiz é fundamental para uma ordem liberal, pois ele deve analisar se a conduta se conformou às normas reconhecidas na ordem espontânea e não considerar o que a sociedade requer no momento. Para Hayek (1985a), o magistrado deve reconhecer os limites da linguagem, mas buscar descobrir a intenção de seus predecessores. Em caso de necessidade de reforma da norma, o juiz deve fazê-lo de forma gradual, não alterando-a conforme seu juízo racionalista. 
Dessa forma, entende Hayek (1985a), ao juiz compete decidir de modo que corresponda ao que as pessoas consideram justo. E se necessário decidir de maneira a frustrar expectativas legítimas, deverá deduzir suas conclusões de premissas expressas e da lógica situacional do caso. Se as normas explícitas entrarem em conflito com o senso geral de justiça, o magistrado deve modificar suas conclusões e fundamentá-las em "alguma norma não escrita que justifique essa modificação e que, ao ser enunciada, tenha a probabilidade de obter concordância geral" (HAYEK, 1985a, p. 136).

O império da lei assegura que a liberdade se dê dentro dos parâmetros da lei. Esta incorpora o conhecimento ou os resultados da experiência passada utilizáveis sempre que o ser humano age conforme essas normas. Quando o indivíduo obedece a norma geral e abstrata, não se submete à vontade de outrem, sendo, portanto, livre. Para Hayek, o juiz deve aplicar a lei imparcialmente e não a usar como meio para atingir determinada concepção de justiça social.

\section{Uma Miragem: A Justiça Social}

Segundo Hayek (1985b), em uma sociedade livre, em que nem os legisladores e nem os juízes podem criar normas específicas para beneficiar determinados indivíduos, a justiça social é uma reivindicação por uma intervenção racionalista artificial para se possibilitar a distribuição discricionária de cotas de bens a diferentes indivíduos ou grupos. É injusta por interferir no resultado de um processo espontâneo e por atribuir às autoridades o dever de ordenar às pessoas o que fazer.

Hayek (1985b) sustenta que o papel do governo é garantir que os indivíduos tenham condições de satisfazer-se livremente em suas necessidades e não satisfazer necessidades particulares. As normas podem regular os meios adequados para o consenso, mas não os fins dos acordos. Dessa maneira, as normas de conduta justa devem ser "normas independentes de fins, que servem à formação de uma ordem espontânea" (HAYEK, 1985b, p. 35).

Nesse contexto, Hayek (1985b) entende que os resultados provenientes de uma ordem espontânea não são justos ou injustos, pois apenas a conduta humana é passível de juízo de valor quanto a sua justiça ou injustiça. Se os meios e as condutas obedeceram os ditames da norma geral de um Estado de Direito ao estipularem um acordo, os resultados advindos dessa relação são justos.

Por isso, para Hayek (1985b), o ideal de justiça social é uma ameaça aos valores de uma sociedade livre, pois os meios e as condutas dos indivíduos são qualificadas por socialmente justas ou injustas. A ideia de justiça social é vazia e sem significado em uma sociedade livre. Só em uma coletividade dirigida, a noção de justiça social ganha sentido, já que os agentes sociais passam a ser orientados por determinações específicas. Se em uma sociedade os serviços e produtos só têm valor para pessoas específicas, para haver uma justiça social é preciso que uma organização estipule uma hierarquia de bens.

Hayek (1985b) argumenta que em uma sociedade tribal, o termo social tinha um significado claro à medida que havia uma estreita relação de solidariedade entre os membros para ajudarem-se entre si. As ações podiam ser ajustadas às necessidades sociais de seus poucos 
membros. Porém, no curso da diferenciação social ocasionado por uma ordem espontânea, em que a sociedade deixou de ser provinciana e tornou-se a Grande Sociedade, as obrigações morais para com alguns não podem se tornar obrigações para toda a sociedade.

Nesse sentido, Hayek (1985b) sustenta que o declínio de uma ordem liberal e o aumento da influência socialista e nacionalista é consequência de um reaparecimento de sentimentos tribais. Com base nisso, alguns grupos e indivíduos buscam influenciar os poderes coercitivos do governo e impor sobre a Grande Sociedade seus interesses e sentimentos.

O problema identificado por Hayek (1985b) é que a justiça social busca tornar a sociedade responsável pela posição material de seus membros. Para isso, é preciso dirigir deliberadamente a ordem espontânea para fins específicos. Na tentativa de corrigir diferenças sociais, o Estado passa a controlar o ambiente, ampliando cada vez mais o seu poder. Esse processo continua até que o governo controle todas as circunstâncias que podem influenciar no bem-estar de qualquer indivíduo.

Dessa maneira, Hayek (1985b) defende que a noção de justiça social é injusta e antissocial, pois protege interesses daqueles grupos que não podem justificar concretamente suas demandas. A ação dos grupos de pressão submete os interesses da sociedade aos objetivos setoriais de tais grupos. Com o tempo, a sociedade é planificada em uma única organização e transformada em um regime coletivista. Consequentemente, a justiça é destruída pelo ideal da justiça social.

$\mathrm{O}$ pensamento intervencionista passa a dominar as autoridades que buscam corrigir as injustiças sociais. Esse caminho leva a sociedade livre à servidão ao dirigir os indivíduos para propósitos visíveis comuns. Logo, conforme Hayek (1985b), o ideal de justiça social é problemático por suspender o mecanismo impessoal de mercado que orienta os esforços individuais, submetendo-os a uma autoridade dirigista que artificialmente tenta promover a distribuição dos bens sociais para indivíduos específicos.

Hayek (1985b) defende que o Estado deve proteger apenas os meios à medida que não sabe quais são os fins particulares deve garantir. Cada indivíduo deve ter a possibilidade de alcançar seus objetivos particulares que não podem ser determinados por um terceiro, a fim de se evitar a coerção da vontade. Assim, o bem-estar geral é o estado de preservação de uma ordem abstrata como um meio auxiliar para que os indivíduos possam alcançar seus propósitos particulares. Quando o governo intervém para promover um ideal de justiça social, ele apenas proporciona uma miragem ao prometer um suposto futuro bem-estar.

Como explica Nogueira (2014), no pensamento hayekiano, a noção de uma justiça social é a que mais ameaça os valores de uma civilização que se pauta pela liberdade. Quando o Estado tenta intervir para promover uma justiça social, o arbítrio de alguns burocratas se impõe sobre a vontade dos indivíduos que, por sua vez, perdem sua própria liberdade. Os direitos sociais e coletivos tornam-se privilégios direcionados a grupos específicos. Essa liberdade positiva promovida pelo Estado provém de um pensamento socialista que causa injustiça já que viola a liberdade negativa.

Segundo Hayek (1983), a crescente influência da concepção racionalista tem substituído gradualmente a palavra moral por social. Defende-se que deve haver uma consciência social, isto é, as ações humanas devem ser orientadas por uma completa compreensão do funcionamento 
do processo social que deve produzir um resultado previsível, o bem social. Exige-se, com isso, que a ação individual seja norteada pela inteligência individual de um burocrata do governo, e não por normas fruto de um processo histórico.

De fato, o princípio do laissez-faire ${ }^{1}$ não propicia um critério adequado para distinguir entre o que é e o que não é admissível em uma ordem livre. Como explica Huerta de Soto (2010), para Hayek, a justiça torna-se corrompida ao se tornar fruto de uma avaliação arbitrária de um órgão político ou de um juiz que não mais julga comportamentos, mas sim resultados. Em contrapartida, o que importa é se a conduta humana é justa ou injusta, e não se os resultados específicos são justos ou não. Logo, a justiça é a compatibilidade do ato do indivíduo com o sistema de normas universais que regem a sociedade.

Conforme Hayek (1983), o governo, em uma sociedade aberta, não pode buscar objetivos específicos, pois não tem a competência de determinar a posição material dos indivíduos ou implementar a justiça distributiva ou social. O Estado de Direito impede que a justiça distributiva substitua a comutativa. A justiça social demanda o dirigismo estatal ou seu planejamento econômico por meio do uso discriminatório e discricionário na aplicação de normas. O resultado é o abandono do império da lei e sua substituição por uma economia de planejamento central. Dessa forma,

Só é possível dar um sentido à expressão 'justiça social' numa economia dirigida ou comandada (tal como o exército), em que indivíduos recebem ordens quanto ao que fazer; e qualquer concepção específica de 'justiça social' só poderia ser realizada num sistema centralmente dirigido (HAYEK, 1985b, p. 88).

Nogueira (2014) explica que, na percepção hayekiana, quando se abandona o Estado de Direito e se estabelecem arranjos artificiais criam-se distorções às normas de conduta justa. A união da democracia com o coletivismo é fatal à liberdade, pois o governo ao interferir mais na liberdade individual aumenta a burocracia e a centralização.

Em contrapartida, Hayek (1983) lembra que a igualdade perante a lei leva à desigualdade material. Não pode haver em uma sociedade livre a aplicação de um modelo de distribuição preconcebido. Os desníveis econômicos não são um mal que justifiquem a coerção discriminatória ou de privilégios. Ainda assim, Hayek (1983) concede que em determinados casos, quando há necessidade legítima de ação governamental, deve-se aplicar o método que mais reduza a desigualdade.

Para Hayek (1983), o livre mercado é o veículo para descentralizar o conhecimento. A intervenção do Estado é negativa já que desarranja a rede de informações do sistema de preços e reduz o escopo da experiência econômica, de forma que, por sua complexidade, a economia não pode ser dominada pela razão humana. Só com a liberdade econômica, as liberdades civil e política podem ser mantidas.

\footnotetext{
1 “O laissez-faire nunca passou de um princípio geral. Na verdade, representou um protesto contra abusos do poder governamental, mas jamais ofereceu um critério que permitisse decidir que funções competem ao governo" (HAYEK, 1985a, p. 69).
} 
Para manter o livre mercado, os indivíduos devem abandonar sua tendência inata para agir em conjunto na busca de objetivos comuns, visto que a civilização é uma sociedade abstrata que se baseia em normas aprendidas e não na busca de finalidades comuns. O mercado implica o respeito por normas, mas não a construção de uma solidariedade espontânea. $\mathrm{O}$ abandono desse quadro destrói o ideal democrático que precisa ser repensado e reconstituído sob uma nova nomenclatura.

\section{Demarquia: Um Resgate do Ideal Democrático}

De acordo com Hayek (1985c), a expansão da atribuição de direitos aos indivíduos em busca do ideal de justiça social transformou a democracia, que deveria ser a salvaguarda dos indivíduos regida pelo império da lei, em um método para decidir qualquer questão da maneira que a maioria determine. A partir disso, a democracia se tornou uma forma de governo que não restringe o organismo governamental.

Segundo Hayek (1985c), o engano que levou a esse caminho foi o de acreditar que o procedimento democrático poderia dispensar os limites ao governo e que o legislativo poderia criar leis para interesses imediatos de alguns grupos de pressão. Com isso, as instituições democráticas foram conduzidas a uma democracia totalitária ou ditadura plebiscitária, em que uma maioria define a forma, o conteúdo e os atributos das leis. O Parlamento, não mais limitado a estabelecer normas gerais, tornou-se um governo arbitrário.

Dessa forma, Hayek (1985c) sustenta que a transição que tem ocorrido na ideia de democracia parte de um sistema em que se decide como resolver certas questões para um sistema em que um certo grupo de agentes declara qualquer coisa de interesse comum, controlando todas as decisões e oprimindo o restante da população. A justiça é pervertida ao declarar justo qualquer medida aprovada pela maioria. Tal deturpação pode levar ao caminho da servidão, pois se o governo é legitimado a decidir questões específicas, com o tempo, os próprios meios passarão a ser determinados pelo governo, conforme Hayek (1983, p. 126) sustenta:

Na medida em que a democracia impõe ao indivíduo apenas normas gerais que ela mesma criou, pode controlar o poder de coerção. Se tentar dirigi-las de maneira mais direta, breve estará só apontando os fins a atingir, deixando que seus funcionários especializados decidam a forma pela qual devem ser alcançados. E, uma vez aceito que as decisões da maioria podem apenas indicar os fins, sendo a consecução destes entregue ao arbítrio dos administradores, em pouco tempo se acreditará que quase todos os meios empregados para alcançar aqueles fins são legítimos.

Nesse contexto, um legislativo único e onipotente corrompe a democracia. Para Hayek (1985c), o governo ilimitado terá de satisfazer os vários interesses para garantir o apoio da maioria, isto é, a lei deixa de ser norma geral e se torna norma específica discriminatória em prol de alguns interesses. E logo os detentores do poder passam a favorecer grupos particulares de cujos votos precisam.

Com efeito, Hayek (1985c) defende o resgate do ideal democrático. Para o autor austríaco, a democracia é um valor muito importante para sociedades abertas. Em primeiro lugar, é o 
único método de transição pacífica de poder descoberto até hoje. Além disso, representa uma garantia à liberdade individual. Ademais, as instituições democráticas possibilitam maior entendimento dos assuntos públicos pela população. Dessa forma, a democracia deve ser entendida como um procedimento para acordo de princípios gerais e não de normas específicas.

O problema salientado por Hayek (1985c) se dá pelo desvirtuamento do ideal democrático. Os democratas desvirtuam a democracia quando entendem que toda e qualquer decisão alcançada democraticamente é uma condição de liberdade. O governo da maioria torna-se ilimitado e ilimitável. A imposição da vontade da maioria a todas às questões da sociedade destrói a ordem espontânea por não permitir que as forças autorreguladoras de uma sociedade livre funcionem no sentido de frustrar os erros passados e manter os acertos antecedentes.

Nesse caminho, conforme Hayek (1985c), quando dado grupo é frequentemente favorecido por dispor de muitos votos, sedimenta-se a crença que tem direito a seus privilégios. Quanto mais favorecido dado grupo se torna, mais ingerência exerce sobre o governo. A partir disso, os grupos de pressão só concordam com a concessão de benefícios a outros grupos se em troca tiverem satisfeitos seus privilégios.

Em consequência, Hayek (1985c) explica que o governo se torna partidário de alguns interesses e conduz a democracia à decadência. Com seu aumento de poder, o governo passa a usar os recursos da sociedade para atender aos desejos de seus grupos de pressão. Pela fórmula da justiça social, distribuem-se gratificações para os grupos privilegiados pelo governo à custa do restante da sociedade. Tal sistema resulta em um governo movido por chantagens e corrupção legalizada, como também se estabelecem leis que a maioria desaprova e cujos efeitos podem levar à derrocada da sociedade.

Para lidar com esse cenário, Hayek (1985c) sustenta ser preciso limitar os poderes dos grupos organizados por meio da limitação dos poderes do governo. As normas gerais permitem evitar os conflitos entre os grupos de pressão e o uso do poder político de modo parcial. O governo deve ser limitado pela coincidência de opiniões entre membros de determinado país segundo normas de conduta justa, isto é, normas gerais e imparciais.

Com efeito, Hayek (1985c) defende que como a democracia é um método ou procedimento para se alcançar determinadas decisões governamentais, ela é corrompida quando ganha atribuições positivas e específicas. Como único método de mudança pacífica governamental é um valor supremo, mas não ilimitado. Em uma sociedade livre, o indivíduo só deve ser obrigado a obedecer às determinações derivadas dos princípios gerais ratificados pela maioria. Ou seja, a maioria só pode concordar quanto a princípios gerais e deve se abster de impor determinações específicas.

A partir disso, Hayek (1985c) sugere que é preciso inventar um novo nome para resgatar o ideal democrático em que a vontade da maioria só se torna imperativa às demais pessoas se estabelecer normas gerais. O termo sugerido é demarquia ${ }^{2}$ que é o controle do governo segundo princípios que a maioria dos cidadãos sustenta.

\footnotetext{
2 “Quase todas as outras formas de governo são derivadas da palavra grega archía, ao invés de kratía. E foi apenas por um simples acidente histórico que, no caso da demokratía, se tenha chegado ao termo democracia. Assim, minha sugestão é
} 
Para Hayek (1985c), as eleições periódicas de representantes fazem com que os partidos se comprometam a cada eleição com a manutenção e implementação de direitos e privilégios específicos para alguns grupos de indivíduos. Para limitar o governo, requer-se retirar das mãos dos partidos políticos tal poder e atribui-lo a pessoas respeitadas no exercício das atividades comuns da vida, que seriam eleitas por sua experiência, sabedoria e justeza, e que pudessem dedicar seu tempo ao aperfeiçoamento institucional a longo prazo. Para tanto, deve-se dividir o poder entre duas diferentes assembleias democraticamente eleitas: a Assembleia Legislativa e a Assembleia Governamental.

Hayek (1985c) propõe que a Assembleia Legislativa seja a casa que represente a opinião do povo sobre as ações governamentais. As normas de conduta justa devem ter a sanção dessa assembleia que, por sua vez, deve definir o direito substantivo limitado aos atributos gerais das normas. Essa assembleia seria composta por homens e mulheres eleitas em idade madura, no mínimo, quarenta ou quarenta e cinco anos, e por períodos razoavelmente longos - quinze anos - que não tivessem de se preocupar com a reeleição.

A décima quinta parte dessa assembleia seria renovada anualmente. Após esse período teriam um emprego público permanente em cargos honoríficos, mas neutros para não se preocuparem nem com eleições nem com seu futuro pessoal. Ao sair dessa assembleia não poderia ir para a Assembleia Governamental.

Os membros só perderiam o mandato por falta grave de conduta ou negligência no cumprimento de seu dever. A fiscalização seria feita por grupo de pares ou ex-pares que poderiam ter o poder de fiscalizar e até destituir representantes, como também atribuir aos membros aposentados das assembleias cargos desde o Tribunal Constitucional até a assessoria de um órgão judicial menor.

Sobre a Assembleia Governamental, Hayek (1985c) propõe que ela se destinaria a cuidar da vontade do povo sobre medidas específicas a serem conformadas às normas gerais estabelecidas pela Assembleia Legislativa. Seria uma assembleia limitada tanto pelas normas da constituição quanto pelas normas de conduta justa estabelecidas pela Assembleia Legislativa. Seu órgão executivo seria o governo que deveria se limitar a determinar quanto gastar.

Ademais, a Assembleia Governamental poderia ser composta por reeleições periódicas de todo o corpo em bases partidárias e sua atividade não poderia ser dirigida pelo comitê executivo da maioria. Este último deveria constituir o governo e atuar no controle da oposição organizada para oferecer um governo alternativo. Essa assembleia estaria obrigada a respeitar, em todas as suas decisões, as normas de conduta justa estabelecidas pela Assembleia Legislativa, e ficaria proibida de emitir ordens aos cidadãos não decorrentes diretamente das normas fixadas pela casa legislativa.

Por fim, Hayek (1985c) sugere à estrutura da demarquia que haja um Tribunal Constitucional independente integrados por juízes profissionais e por ex-membros da Assembleia Legislativa e talvez da Governamental. Esse Tribunal deveria ficar submetido a 
suas decisões anteriores e qualquer mutação das decisões anteriores teria de ocorrer segundo um processo de emendas conforme estipulado na Constituição. Esse ente não poderia tomar medidas coercitivas, algo que estaria a cargo da Assembleia Legislativa, salvo em períodos de emergência.

A Constituição deve estabelecer normas de organização e, excepcionalmente, normas gerais de conduta dispondo dos atributos gerais que as leis específicas devem possuir. $\mathrm{O}$ texto constitucional deve regular o processo de feitura de leis, evitar a sobreposição entre os poderes governamentais na aplicação de normas em que se funda a ordem espontânea da sociedade, e estabelecer o uso de recursos materiais confiados à administração governamental para a prestação de serviços aos indivíduos.

Dessa forma, segundo Hayek (1983), o governo democrático deve ser aceito como método para a tomada de decisões, mas não como autoridade para estabelecer que decisão deve ser tomada. Em uma ordem liberal deve haver limites explícitos para que os problemas possam ser resolvidos pela via democrática. A democracia deve impor apenas normas gerais que possam controlar o poder de coerção. Assim, o liberalismo inclui o método democrático, mas limita o poder da maioria.

Portanto, em uma ordem liberal segundo F. A. Hayek, perpetrada pelos elementos do Estado de Direito, não se pode criar normas artificialmente, não se deve buscar uma miragem de justiça coletivista e se deve repensar a democracia dentro de limites de normas de conduta justa. A essas formulações hayekianas, algumas críticas podem ser construídas.

\section{Críticas às Concepções Hayekianas de Direito e Democracia}

O presente tópico busca discutir criticamente alguns elementos da relação entre direito, justiça e democracia em F. A. Hayek. As críticas se darão em três sentidos: a liberdade e a justiça são concebidas apenas em seu sentido negativo, a democracia é entendida apenas nos sentidos formal e procedimental, e ao juiz é atribuído o dever de assumir um papel de Hércules no descobrimento de normas mais adequadas aos casos concretos.

\subsection{Liberdade e Justiça Negativas}

No pensamento de Hayek, a liberdade se dá no sentido negativo, isto é, o indivíduo não pode ser governado pela vontade coercitiva de um terceiro. Ademais, é injusta a ação positiva do Estado visando a alcançar uma concepção de justiça social, já que aumentará a coerção sobre a sociedade em benefício de alguns grupos ou indivíduos. Assim, a liberdade e a justiça são concebidas apenas em seu sentido negativo.

Contudo, liberdade e justiça exclusivamente negativas (não coercitivas) sem algum grau de liberdade e justiça positivas (de oportunidades) são concepções adequadas? Em países subdesenvolvidos, que não passaram por uma revolução industrial e tecnológica como os países mais avançados, a garantia de uma liberdade apenas formal pode desassistir uma grande quantidade de pessoas que precisam da ação ativa do governo na promoção de direitos sociais que possibilitem liberdade de oportunidades. 
De acordo com Gray (1980), Hayek oferece um liberalismo que serve a uma ordem liberal ameaçada pelo coletivismo, mas que não responde aos anseios de sociedades subdesenvolvidas. Como lembra Nuez (2013), Hayek sustenta que a promoção da liberdade positiva é contrária à civilização e a uma ordem liberal. Porém, o autor austríaco defende que a coerção é legítima para estabelecer uma renda mínima a cargo do Estado para auxílio dos desamparados ${ }^{3}$, o que não se coaduna com sua formulação liberal.

O liberal social brasileiro, Merquior (1982), aponta que a liberdade econômica é precária sem o aperfeiçoamento da igualdade. O liberalismo implica o aperfeiçoamento da igualdade, pois como o mercado se rege por critérios de eficiência e rentabilidade, não de justiça e equidade, ele cria riqueza, mas não a distribui competentemente. Por isso, é preciso corretivos dos efeitos do mercado, sem que se danifique sua ordem espontânea. O livre mercado não reduz as desigualdades de ponto de partida que existem entre indivíduos devido ao berço ou educação.

Para Merquior (1982), a ação corretiva do Estado, que visa a mitigar as desigualdades dos pontos de partida, pode contribuir na promoção da liberdade de oportunidades. Isto é, condições para que cada um busque suas aspirações conforme sua vontade. Tal liberdade implica supressão de privilégios, e não um igualitarismo em que a igualdade é um valor-fim. Essa noção não implica, em termos hayekianos, em uma busca por uma miragem social que pode levar a uma democracia totalitária.

Como Merquior (1983) sustenta, o Estado pode reconhecer que há barreiras econômicas e sociais que impedem a liberdade e atuar no sentido de mitigar a falta de oportunidades, promovendo o exercício da liberdade em prol do bem comum. Dessa maneira, o Estado pode ser refuncionalizado para promover condições aos mais vulneráveis e desassistidos de oportunidades.

Assim, o postulado hayekiano que a intervenção estatal na ordem espontânea com o fim de aprimorar a justiça em sentido positivo é uma miragem coletivista parece um exagero, posto que medidas comedidas do Estado podem contribuir na promoção de oportunidades.

Nesse ponto, Nuez (2013) destaca que Hayek considera a ação do Estado na ordem espontânea temerária, porém o autor austríaco não explica como uma ordem espontânea autônoma leva necessariamente a uma ordem liberal. O ceticismo hayekiano ${ }^{4}$ à ação do Estado é substituído por um profundo apego à crença no progresso rumo a uma ordem liberal.

Assim, a justiça e a liberdade apenas negativas em Hayek apresentam um paradoxo. Segundo Nuez (2013), pela doutrina evolucionista, as normas específicas que buscam alcançar uma concepção de justiça social podem também ser consideradas como espontaneamente evoluídas.

\footnotetext{
${ }^{3}$ Hayek (1985b, p. 108) afirma que "não há razão para que, numa sociedade livre, o governo não garanta para todos uma proteção contra sérias privações sob a forma de uma renda mínima garantida, ou um nível abaixo do qual ninguém precise descer".

4 “Eu faço parte daquele grupo ao qual os grandes filósofos escoceses do século XVIII e pessoas como Edmund Burke pertenceram, os antigos Whigs. Descobri, porém, que tais homens acharam uma expressão muito melhor para classificarem a si mesmos. Alguns deles, a começar por David Hume, consideravam-se Whigs céticos. Desta forma, eu agora classifico a mim mesmo como um Whig cético" (HAYEK, 1981, p. 16).
} 
Se toda evolução espontânea gera liberdade negativa, deve-se tão somente deixar o livre curso da história seguir. Porém, se tal evolução pode levar a uma via que demanda uma ação intencional, a coerção do Estado se faz necessária para adaptar a sociedade à liberdade negativa, necessitando-se, portanto, de uma ação racionalista em prol da ordem liberal.

\subsection{Democracia Procedimentalista}

No pensamento hayekiano, o Estado de Direito e a democracia devem ser procedimentalistas. O governo não deve perpetrar as leis do Estado com conteúdo moral, social ou com fins específicos de qualquer gênero, posto que as normas devem derivar de uma ordem espontânea, caracterizadas pela universalidade e imparcialidade. E a democracia deve ser apenas um método de troca de poder procedimental.

Contudo, como Pievatolo (2006) aponta, no percurso da ordem espontânea, muitas escolhas arbitrárias são tomadas. A história do direito não é feita por ações neutras que, necessariamente, levam ao estabelecimento de uma ordem liberal e a um Estado de Direito procedimentalista. Logo, as normas jurídicas são mais que formais, pois dispõem de conteúdo substancial que serve ao interesse ou benefício de algum grupo ou perspectiva de mundo.

Dessa forma, segundo Pievatolo (2006), o Estado de Direito e a democracia como normas procedimentais podem ser preenchidas por conteúdos normativos frutos de uma concepção liberal ou totalitária. O curso histórico pode levar ao preenchimento das normas por um pensamento liberal ou uma insuportável tirania. Hayek se socorre dos juízes para garantir uma ordem liberal, mas não há tal garantia. O próprio Poder Judiciário pode criar uma ditadura da toga coletivista.

Nesse sentido, Pievatolo (2006) sustenta que mesmo que uma norma fique restrita à obediência do atributo da universalidade, o legislador ou juiz poderá usá-la arbitrariamente, através de um processo de generalização, para favorecer determinado grupo ou determinados interesses. Além disso, postular que uma norma formal não tenha fins particulares é impossível, já que o fim de uma regra nasce na relação entre um agente que decide e a regra. Logo, a interpretação da norma geral resultará na concretização de fins particulares.

Nessa esteira, se o Estado de Direito e a democracia devem estabelecer apenas uma noção formal para preservar a liberdade negativa, é possível que, quando da aplicação de normas desprovidas de conteúdo específicos, seus efeitos se tornem arbitrários. Dessa maneira, um Estado de Direito e uma democracia que impedem o abuso de poder e preenchem de conteúdo as normas abstratas sempre no sentido que beneficiem uma ordem liberal é um postulado que não resta provado.

De acordo com Pievatolo (2006), o Estado de Direito e a democracia hayekianas, que contrapõe o direito como projeto racionalista ao direito como resultado da ordem espontânea, exclui o Rechtstaat continental e o Estado Democrático moderno, sobrando apenas uma forma autêntica de Estado de Direito, a saber, o rule of law anglo-saxão, que se fundamenta na tradição e no direito jurisprudencial. Só este último é o governo da lei, sendo os outros modelos, na concepção hayekiana, governo dos homens com suas escolhas racionalistas arbitrárias. 
Com efeito, Merquior (1982) ainda salienta que Hayek não se poupa de dar conteúdo racionalista e específico às normas de sua concepção de Estado de Direito e democracia. Afora sua proposta de renda mínima aos mais desfavorecidos, sua concepção de demarquia é um projeto de reforma deliberada dos atuais sistemas democráticos que vai de encontro a sua ideia de evolução da ordem espontânea. Assim, a demarquia se revela um exercício racionalista que intervém no curso da ordem espontânea.

Em contrapartida, Merquior (1982) salienta que sem um suporte de um determinado comportamento político, a democracia é uma abstrata ficção jurídica. A democracia como ação evoca uma sociedade consciente de sua cidadania e que pode exercer sua liberdade civil. Não são apenas as normas que limitam o governo, mas também o exercício da cidadania que modera o poder do governo. Ee com a promoção da liberdade de oportunidades que se garante a autenticidade democrática. Portanto, uma ordem de mercado é necessária à democracia, mas não suficiente.

Assim, segundo Merquior (1983), o Estado de Direito e a democracia que só visam a manter o reino da legalidade dificilmente atendem à vontade democratizante das sociedades liberais e não satisfazem as necessidades sociais de países subdesenvolvidos em que direitos civis e políticos não são assegurados. Tal ordem legal não garante automaticamente liberdade, pois não pode gerar oportunidades suficientes para o exercício mais pleno da individualidade dos hipossuficientes.

\subsection{Juiz Hércules}

O teórico do direito, Ronald Dworkin (2014) postulou um magistrado ideal - Juiz Hércules - para a interpretação e aplicação do direito. Seria um juiz de conhecimento, capacidade, tempo e isenção abundantes. Deveria buscar a resposta correta em uma interpretação integradora de todos os princípios e normas jurídicas. Em alguma medida, a defesa hayekiana do common law, concentrando nos magistrados uma interpretação que respeite e integre a ordem espontânea aos casos concretos, lembra o ideal dworkiniano.

Em primeiro lugar, a concepção de Estado de Direito hayekiana em que o juiz só descobre a norma, mas não a cria, pressupõe que o magistrado não é intérprete-criador de normas jurídicas não contidas no ordenamento legal ao efetivar o direito no caso concreto. Talvez por isso Hayek (1985a, p. 138) sustente que "na maioria das vezes, haverá apenas uma solução correta", pois, a interpretação se dá através da capacidade de integrar as normas à ordem espontânea.

Hayek pressupõe um modelo interpretativo formalista em que a atuação do juiz é a de um descobridor de normas gerais de uma ordem espontânea. Pressupõe-se um agente cognoscente da ordem espontânea e das normas adequadas a cada caso concreto. Nesse modelo, conforme Vigo (2010), o juiz não pode formular preferências ou restringir a interpretação das leis positivadas ou das normas da ordem espontânea, pois deve apenas fazer a subsunção da norma geral ao caso concreto. Pressupõe-se certo nível de perfeição, previsão e clareza na integração das normas aos casos concretos. 
A partir disso, Hayek propõe que o magistrado seja uma boca da tradição e da jurisprudência. Esse modelo formalista e cognitivista de enxergar o direito tem sido alvo de críticas. Esse modelo, de acordo com Atienza (2016), postula apenas critérios formais, mas não se ocupa das questões de conteúdo que qualificam os discursos e as decisões. Fundamentase na crença que o intelecto do magistrado é capaz de derivar decisões de normas gerais de conduta justa para todos os casos. Porém, nem todas as normas utilizadas são explícitas, sendo muitas delas implícitas, pressupostas e indeterminadas.

Isso se dá porque a linguagem tem uma dimensão não explícita. Segundo Vigo (2010), o modelo formalista de interpretação pressupõe que a linguagem tem um único, claro e preciso significado, do qual emana o domínio linguístico do legislador e dos juristas que resguardam a linguagem jurídica de imperfeições sintáticas, pragmáticas e semânticas. Com isso, toda interpretação já é prefixada por meio de um caminho espontâneo a ser seguido. Nesse modelo, a interpretação fica diferenciada da criação jurídica e o juiz procura ser fiel à ordem espontânea a fim de reconstruí-la sistematicamente.

Dessa forma, Hayek pressupõe que o direito, fruto da ordem espontânea consolidada na tradição e nos tribunais, deve levar os juízes a ter uma postura formalista ante as normas gerais consolidadas. O magistrado deveria reconstruir dedutivamente o pensamento intrínseco da jurisprudência, por meio do descobrimento imparcial da ratio decidendi para subsumi-la ao caso concreto. Dessa maneira, garantir-se-iam a segurança e previsibilidade jurídica e se limitaria o poder criador de normas derivado do racionalismo dos Parlamentos.

Porém, como explica Just (2014), a maior complexidade social nas últimas décadas levou o discurso judicial a abandonar uma perspectiva formalista de interpretação da lei e do contrato e consolidar uma hermenêutica em que se criam normas no ato de decidir, justificando-se as soluções das lides concretas por meio da exposição de motivos da decisão em regimes democráticos. Ou seja, a decisão judicial deve valorar no ato de interpretar-aplicar a norma geral e abstrata ou a jurisprudência consolidada ao caso concreto, legitimando-se por meio de uma fundamentação jurídica razoável perante os atores envolvidos.

O receio de Hayek é de que o racionalismo criador de normas diminua cada vez mais a liberdade dos indivíduos ao expandir o poder do Estado. Porém, isso também pode acontecer no caso de juízes descobrirem as normas gerais consolidadas na tradição. Sua interpretação pode levar a decisões arbitrárias que não podem ser reconstruídas, mas simplesmente aceitas como fruto da ordem espontânea.

Por isso, analisando o papel do magistrado em Hayek a partir de uma perspectiva hodierna, em que o Poder Judiciário ampliou seu poder exponencialmente no sentido de concretizar uma justiça social, mesmo em países de common law, parece ingênua a pressuposição de que o juiz pode ser apenas um descobridor formal da norma adequada ao caso concreto. Tribunais que devem meramente descobrir as leis do passado podem usar os precedentes como instrumentos de dominação com fundamento em argumentos de autoridade na ordem espontânea. Essa postura pode abrir espaço para a ditadura da toga, que só tem de responder às decisões da jurisprudência passada. 


\section{Considerações Finais}

O presente trabalho teve o objetivo de estudar a concepção hayekiana de direito, justiça e democracia para uma ordem liberal. Quanto ao primeiro conceito, investigou-se a relação entre direito e liberdade em Hayek através do conceito de normas de conduta justa. Quanto à noção de justiça hayekiana, estudou-se as críticas do autor austríaco à busca de justiça social. No tocante à democracia, estudou-se a preocupação de Hayek em resgatar o ideal democrático como método pacífico de troca de poder e sua formulação de demarquia.

A formulação hayekiana estudada nesse artigo pode ser resumida assim. O Poder Executivo e o Poder Legislativo devem ser repensados em um regime de demarquia com duas Assembleias, Governamental e Legislativa, e um Tribunal Constitucional, a fim de se resgatar o ideal de democracia como método procedimental de troca de poder pacífico. Isso possibilitaria a limitação do governo e diminuição de seu poder coercitivo, liberando o direito privado das normas organizacionais e do aparato burocrático do poder público.

Com isso, seria possível diminuir a amplitude da produção de normas específicas que buscam um ideal de justiça social inalcançável. O direito seria consolidado nos tribunais por meio de normas gerais provenientes da ordem espontânea e descobertas pelos juízes que, em respeito à jurisprudência e aos precedentes, tomariam decisões respaldadas na tradição e no quadro moral da sociedade. Isso consolidaria o império da lei através de normas de conduta justa que preservassem a imparcialidade, a generalidade e a segurança e previsibilidade jurídicas.

Porém, as formulações hayekianas apresentam algumas dificuldades. Em primeiro lugar, a justiça e a liberdade estritamente negativas nem sempre possibilitam mais liberdade. Em países subdesenvolvidos, mesmo que haja a disposição de um aparato político-jurídico de normas gerais, a falta de oportunidades e a inação do Estado em promovê-las diminuem a possibilidade do exercício da cidadania, da democracia e da competição no mercado daqueles que não dispõem de meios para alcançar seus objetivos.

Ademais, se a democracia em um Estado de Direito for apenas um método procedimental para garantia de troca de poder, a dimensão cidadã perde espaço, inclusive para controlar o governo. A justiça positiva não é necessariamente maléfica à democracia, ainda que, como bem alertou Hayek, sua expansão ilimitada possa representar uma distorção do Estado de Direito. Há um grau de justiça positiva que o Estado pode promover e que deve ser controlada no exercício democrático.

Por fim, a concepção do papel dos magistrados no pensamento hayekiano parece questionável à medida que juízes nem sempre são capazes de descobrir as normas mais adequadas que necessariamente levarão à consolidação de uma ordem liberal. Inclusive, vê-se hodiernamente que a expansão da atuação dos magistrados, mesmo em tradições de common law, tem representado a criação de normas que nem sempre levam a mais liberdade. A interpretação formalista pressupõe um juiz cognoscente que seria capaz de exercer um papel de Hércules no ato de julgar. Pressuposição essa que não parece razoável. 


\section{Referências}

ATIENZA, Manuel. As razões do direito: teoria da argumentação jurídica. Rio de Janeiro: Forense Universitária, 2016.

DE SOTO, Huerta Jesus. A Escola Austríaca: mercado e criatividade empresarial. São Paulo: Instituto Ludwig von Mises Brasil, 2010.

DWORKIN, Ronald. O império do Direito. São Paulo: Martins Fontes, 2014.

GRAY, John N. F. A. Hayek on Liberty and Tradition. The Journal of Libertarian Studies, Oxford University, v. 4, n. 2, 1980.

HAYEK. F. A. Hayek na UnB: conferências, comentários e debates de um simpósio internacional realizado de 11 a 12 de maio de 1981. Brasília: Editora Universidade de Brasília, 1981.

Os fundamentos da liberdade. São Paulo, Visão, 1983.

. Direito, legislação e liberdade: uma nova formulação dos princípios liberais de justiça e economia política. V. I: Normas e Ordem. São Paulo: Visão, 1985a.

. Direito, legislação e liberdade: uma nova formulação dos princípios liberais de justiça e economia política. V. II: A miragem da justiça social. São Paulo: Visão, 1985b.

. Direito, legislação e liberdade: uma nova formulação dos princípios liberais de justiça e economia política. V. III: A ordem política de um povo livre. São Paulo: Visão, 1985c.

JUST, Gustavo. Interpretando as teorias da interpretação. São Paulo: Saraiva, 2014.

MERQUIOR, José Guilherme. A natureza do processo. Rio de Janeiro: Nova Fronteira, 1982.

. O Argumento Liberal. Rio de Janeiro: Nova Fronteira, 1983.

NOGUEIRA, Jorge Henrique de Saules. O Direito como Salvaguarda da Liberdade: elementos da Teoria do Direito de F. A. Hayek. MISES: Revista Interdisciplinar de Filosofia, Direito e Economia, v. 2, n. 2 (Edição 4), 2014.

NUEZ, Paloma de la. La política de la libertad: estúdio del pensamento político de F. A. Hayek. Madrid: Unión Editorial, 2013.

PAZ, A. Os Fundamentos do Estado de Direito no Pensamento de F. A. Hayek. Mises Journal [Internet]. Disponível em: https://revistamises.org.br/misesjournal/article/view/1308. Acesso em: 27 out 2020.

PIEVATOLO, Maria Chiara. Rule of law e ordem espontânea. A crítica do Estado de Direito eurocontinental em Bruno Leoni e Friedrich von Hayek. In: COSTA, Pietro; ZOLO, Danilo (Orgs). O Estado de Direito: história, teoria, crítica. São Paulo: Martins Fontes, 2006.

VIGO, Rodolfo Luis. Interpretação jurídica: do modelo juspositivista-legalista do século XIX às novas perspectivas. São Paulo: Editora Revista dos Tribunais, 2010. 